\title{
The Role of Talent Management as Distinctive Capabilities for SMEs
}

\author{
Annisa Ciptagustia, Kusnendi \\ Management Department, Faculty of Economic and Bussiness Education \\ Universitas Pendidikan Indonesia \\ Bandung, INDONESIA \\ annisacipta@upi.edu
}

\begin{abstract}
Talent management is a significant issue for organization in the competitive landscape. The key of talent management is the process result in human resource function to find, develop and maintenance the best employees. The processes call it distinctive capabilities with valuable, rare, imperfectly imitable, and non-substitutable (VIRN) characteristics. This research aims to analyse the influence of talent management as distinctive capabilities, especially for small medium enterprises. The data was analysed by simple regression analysis. This research was conduct in Rattan Furniture Company in Cirebon, the biggest producer in Indonesia and chosen 70 company's samples selected using proportional random sampling. The result indicated typical high and low distinctive capabilities in for SMEs especially rattan furniture Company are positively influenced by the talent management.
\end{abstract}

Keywords-talent management, distinctive capabilities, VIRN

\section{INTRODUCTION}

Rattan furniture industry in Indonesia has critical problem, they are lack of employee as a result in their performance. The cause of the problems of the problem is because the products are not competitive enough in both of the products design and prices offered. On the other hand, the management of the company doesn't focus on their resources such as human resources. [1] The Commerce Department data show that in 2004 to 2009, rattan furniture export was also decreased by $45 \%$. Still in the same year, the total installed capacity of finished rattan products (rattan furniture) and realization of production were decreased $30 \%$ in the following 4 years.

Besides that Indonesia is the largest country that produces rattan in the world, an estimated $80 \%$ of rattan raw materials in the world is produced by Indonesia which are spread on the island of Borneo, Sumatra, Sulawesi and Papua island with a production rate of about 622000 tons / year. One of the biggest producers of rattan furniture is Cirebon. [2]

Many believe that the problem was due to government regulations that decided to reopen the export of raw rattan in 2005 through a decree of the Minister of Trade No. 12 / MDAG / PER / 6/2005 on the export of rattan. This was turning rattan furniture industry. However, based on the results of field research conducted by the Commission in Cirebon, rattan business operators stated that they had never encountered difficulties in obtaining raw materials of rattan cane from farmers and traders in Sumatra, Kalimantan, and Sulawesi. Thus it can be seen that the amount of domestic production of cane were so much more influenced by market conditions / demand for furniture products overseas, because $80 \%$ of the market demand for rattan furniture came from abroad. [3]

Many experts believe that capability is a source of sustainable competitive advantage. [4][5][6][7][8][9] Several previous studies revealed that is a significant correlation between distinctive capabilities and performance of SMEs or competitive advantage, and indicators of distinctive capabilities based on [10] the result indicates all performance SMEs indicators could be explained by the distinctive capabilities and average equity performance got the highest correlation by $64.4 \%$. Another research from Ulrich (1997) used indicators of distinctive capabilities with organizational capabilities because enhance performance, organizational capability associated with groups or individual competencies that collectively turn into organizational competencies. [11] But John Kay (2001) uses three indicators to explain distinctive capabilities, such as architecture, reputation, and innovation. [6] No research to uses John Kay indictors to measure distinctive capabilities.

And the other hand, organization be required to find and allocate the opportunity through utilize what they have. It is a resource based view (RBV) concept. RBV assumed that internal organization such as resource and capabilities as a source of competitive advantage has valuable, rare, imperfectly imitable, and non-substitutable (VIRN) characteristics, they are intangible assets. The reason is because hard to imitate with competitors. To gain a competitive advantage, there are two categories of resource needed, tangible and intangible assets. Intangible assets consist of resources and capabilities. [8] Capability is derived from the human resources as well as the organization's activities. However, it requires talented human resources which are obtained the company through talent management strategies because talent management has a VRIN characteristic. [12]

\section{THE RELATIONSHIP BETWEEN TALENT MANAGEMENT AND DISTINCTIVE CAPABILITIES}

According Day (1994), capability is a set of knowledge that makes the activity of organization more productive to uses 
their assets. [3] However, capabilities are the notion of routines, according to Collis (1994) divided into three categories, they are: In the first category, capabilities are basic functional activities of the firm. The second category includes those activities that allow the firm to learn and adapt to changing environmental condition over time. Lastly, "metaphysical capabilities allow the firm "to recognize the intrinsic value of other resources or to develop novel strategies before competitors. [14] But to gain competitive advantage needed capabilities, such as (1) non-contingent capabilities and (2) distinctive capabilities. Non-contingent capabilities are basic capabilities to being "well" organization than others, and distinctive capabilities make organization distinguish. [5]

The core of distinctive capabilities is combination between core competence and dynamic capabilities. Core competence based on inside-out model and dynamic capabilities is firm ability to integrate their internal and external competence. On the other hand, a distinctive capability is unique combination from human resource competence with firm competence. [9]

Based on Resource Based View (RBV), resource and capabilities who has compete there are valuable, rare, and imperfectly imitable and non-substitutable (VRIN) and came from internal organization such as tangible and intangible assets. Tangible asset consist of financial assets and physical assets. On the other hand intangible asset embody (1) asset such as intellectual property, organizational assets, reputational assets and (2) capabilities such as know-how, managerial know-how, relationships routines). Based on that, capabilities consisting of functional activities to adaptation and metaphysical capability or a set of strategy choice reflected in organizational routines or operational routines. A routine is current and future behaviour pattern to application their know-how of the organization to process their input. [15] Operational routines will increase their input more productive and also has value added. This operation also a set of activities from individual or team work in organizational process whose became pattern or culture. These activities able to value added creation from organizational routine to hard duplicate with competitors. That the reason why distinctive capabilities has influence organization performance such as source competitive advantage.

In accordance with The RBV concept, the uniqueness of the organization seen based on collaboration of several resources. The perfect combination between assets and capabilities most likely has VIRN characteristic or called it distinctive capabilities can be improved from human resource with their system. [16]

Human resource is critical success for organization. Therefore, each organization in charge to have strategy in maintenance their employee in orders to keep their loyalty and engaged. Because losing a talented employee its mean lose their knowledge and also high cost. So, war of talent became emerging phenomenon.

According to Stuarz, Kotze and Dunn, talent has two components there are ability and capability. Ability is current performance and capability is potential performance that has prediction and overpowered in the future. [17] Talent not only knowledge, ability, skill or mental characteristics but can improved with innovation to solve future problems. [18] Is the reason why important to develop the talented people became loyal to organization and it called talent management.

Talent management makes the company capable in finding, retaining and developing their talented human resources. This is difficult to be imitated by another company, although it has the same human resources, how to manage them will differ one and another. [20][9] Talent management activities cannot be separated from the function of human resource management. That is combination from talented people and also their system that has routines and not instantly system. That the reason why talent management can be a distinctive capability for organization. [5]

Therefore, Armstrong (2006) defines talent management as a process that is crucial to ensure the quality and quantity of people or employees needed for current and future business activities. It is a series of integrated activities to ensure the organization to be more attractive, survive, motivated and undertakes the development of the talented people for recent and future need. It can be concluded that the talent is one of the core resources for the organization. [19]

For rattan Furniture Company, their product will be easy to be imitated by competitors, but their artisan and their employees it's hard to imitate quickly. Because their complete combination from their competence, knowledge, experience, passion, taste, and ability to face the competition. The talent management implication of a company is human resource management system and innovative routines. All of these are difficult to replaced and replicated in quick time.

Based on the previous explanation, the writer is interested in studying more about the effect of talent management as a distinctive capability rattan furniture industry. It can be concluded that the hypothesis of the research is that distinctive capability positive affected by talent management.

\section{RESEARCH METHODOLOGY}

This Primary data were collected through a questionnaire survey distribute to 70 furniture rattan companies member ASMINDO Cirebon. Talent management measured using characteristic by Amstrong (2006) include HRM Strategy, Attraction and Retention program, talent audit, role management, performance management, learning and development, succession planning, career management. And distinctive capabilities measure by John Kay (2001) indicators, such as architecture, Reputation, and Innovation.

Unit analysis for these researches are companies who members ASMINDO Cirebon by 85 companies. And only 70 companies being sample using Slovin and Slovilla formula with error $5 \%$ with 4 people each companies for respondent such as designer, craftsman, 2 employees from Human resources department and export-import department. The data is categorized into three criterions: low, moderate, and high. Furthermore, the data is analysed using simple regression analysis. 


\section{FINDINGS AND DISCUSSION}

From descriptive analysis statistics with $95 \%$ confidence level, it is found that, generally, talent management strategy is in average category. The highest indicators are motivation and recognition, employee engagement, relationship between the employee and their role, career planning for talented people, internal recruitment.

And the lowest indicators are comfort to work, change to evolve, and leadership succession. It indicates the companies have not been able to create enough work convenience for its employees. Show as Figure. 1

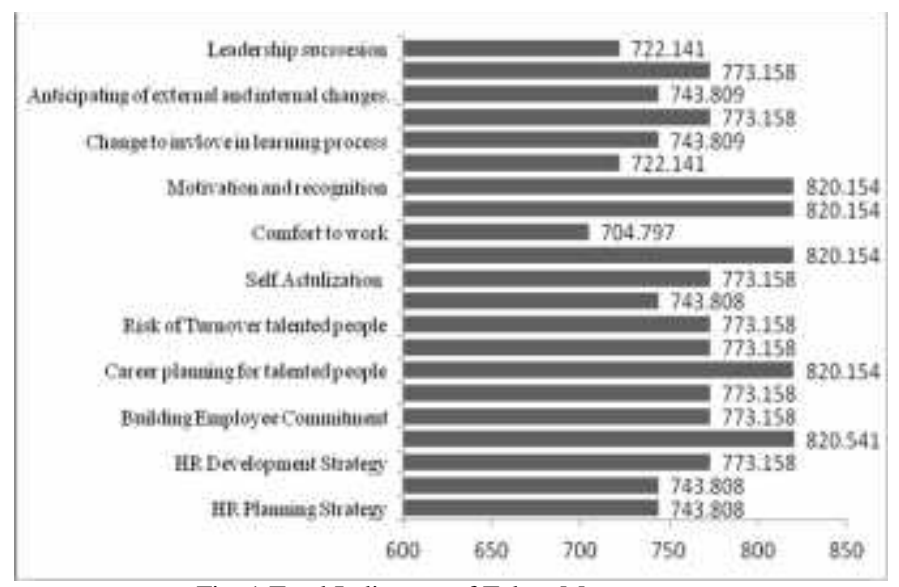

Fig. 1 Total Indicators of Talent Management

From descriptive analysis statistics with $95 \%$ confidence level, it is found that, generally, Distinctive capabilities rattan furniture industry Cirebon categorized moderate. The highest indicators are: innovative (process and protect the result). The analysed of this situation, rattan furniture industry has shortages of raw materials based on government regulation on 2000-2005. The implication is with strategy choice in innovation to substitute their raw material (rattan) with plastic and combination with other materials such as wood and iron. The architecture at second level with establish good relationship supplier of raw rattan material. And has bad relationship with competitors. And also has moderate level of reputation especially to offer quality and guaranteed of product.

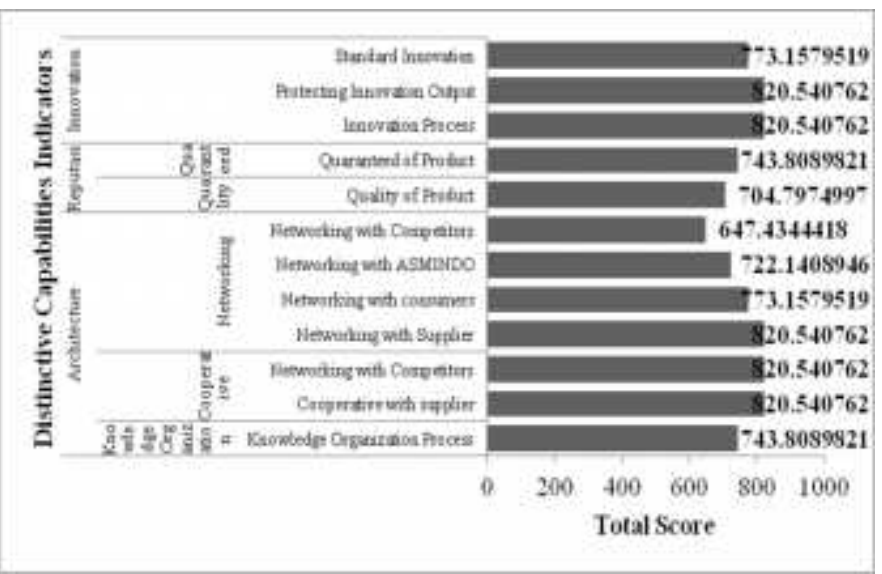

Fig. 2 Score Total Distinctive Capabilities Indicators
The lowest score is networking with competitors. This is because, mostly foreigners owner of rattan furniture companies. So its implication to communicate assumed they are potential competitors. Show as Figure 2.

Based on the data processing result, the level of distinctive capability of rattan furniture industry Cirebon has positively and significantly influenced by the level of talent management of $56,7 \%$. This is because significance value of 0.000 which is smaller than the significance level was set at 0.05 and test $6.045(6.045>1.98)$. Show as Table 1.

TABLE I. COEFFICIENT

\begin{tabular}{|c|c|c|c|c|c|c|c|}
\hline \multirow{2}{*}{ Model } & \multicolumn{2}{|c|}{ Unstandardized Coefficients } & \multicolumn{2}{|l|}{ Standardized } & \multirow[b]{2}{*}{ Sig. } & \multirow{2}{*}{$\begin{array}{c}\mathrm{T} \text { table } \\
(\mathrm{df}=70-1- \\
1=69)\end{array}$} & \multirow[b]{2}{*}{ Conclusion } \\
\hline & B & Std. Error & $\frac{\text { Coefficients }}{\text { Beta }}$ & $\mathrm{t}$ & & & \\
\hline Model Y & 17.173 & 2.841 & & 6.045 & 0.00000 & & \\
\hline $\begin{array}{c}\text { Talent } \\
\text { Management } \\
\text { (X) }\end{array}$ & 0.347 & 0.037 & 0.753 & 9.44 & 0.00000 & 1.98 & Ho Rejected \\
\hline
\end{tabular}

Dependent Var: Distinctive Capabilities $(Y)$

These results can prove the statement raised by Scott Jackson (2012) which has been doing theoretical study of a variety of research and literature that talent management can build distinctive capability of the organization with their routines in human resource management function to recruiting, to develop, and to retaining their employees. Its implied in organization to produced innovating activity from talented people with high motivate, able and engage. As well as theoretical study of Hanif, Masood, Tariq, dan Azhar (2012) that talent management is a source of sustainable competitive advantage because has VIRN characteristic in their human resource system who became architecture of the company to hard replicable quickly by competitors. On the other hand, has distinctive capability that makes the organization more friendliness than others for employees, supplier, and also the competitors. Basic of the firm its contracts and relationship, so friendliness it means good relationship with all stakeholders. Can apply to keep and motivate the employee in organization. All the process is organizational capabilities who integrating with process and procedure or strategic as architecture of the organization, these hard to imitate and duplicate quickly.

Associated with theoretical concept, architecture is operational routines who applied the power of knowledge sharing and its source of organizational knowledge. In rattan furniture industry, employee are the most important because core activities is to produce product (craftsman), and other employee like export and import dept., human resource dept. and production dept. (designer) all combined to work each other in product. That is important to keep and motivate the employee.

\section{CONCLUSION AND SUGGESTION}

Based on the result of the descriptive and verifiable analysis uses simple regression, talent management in rattan furniture industry in Cirebon is in average categories and has not been able to create enough work convenience for its employees, which means that the company has not fully implemented the strategy. And level of distinctive capability 
of rattan furniture industry categorized moderate and need to fix the relationship with competitors. And the level of distinctive capability of rattan furniture industry Cirebon has positively and significantly influenced by the level of talent management.

Overall this research can be proved what the critical about Jhon Kay indicators about distinctive capabilities. The answer is how about to find the source of the distinguish capability.

Therefore, it is suggested to do further research on the factors that influence talent management, especially in the rattan furniture industry. And need to be conducted in order to measurement competitive advantage use resource based view indicators or VIRN.

\section{References}

[1] Interview with owner Larissa

[2] ASMINDO Report 2010

[3] KPPU "Positioning Paper KPPU terhadap KEBIJAKAN EKSPOR ROTAN 2012.

[4] Grant, Robert M. 2010. Contemporary Strategy Analysis. 7th Edition. A Jhon wiley \& Son, Ltd, Publication. United Kingdom.

[5] Jackson, W.B Scott. 2012. HR is Businss: Achieving Competitive Advantge Through Strategic Talent Management. HR.Research Oxford Business University. UK. p. 1.

[6] Kay, John. 2001. Foundation of Corporate Success: How Business Strategues Add Value. Oxford University Press.UK.

[7] Barney, Jay B dan Delwyn N.Clark. 2007. Resource-Based Theory: Creating and Sustaining Competitive Advantage. UK: Oxford University Press.

[8] Hall, Richard. 1992. The Strategic Analysis of Intangible Resources. Strategic Management Journal, Vol. 13, Issue 2. P.134-135.
[9] Cheese, P; Robert J Thomas and Elizabeth Craig. 2007. The Talent Powered Organization "Strategies for Globalization, Talent Management and High Performance". Kogan Page. London and Philadelphia.

[10] Michael A. Hitt; R. Duane Ireland. 1985. Corporate distinctive competence, strategy, industry and performance. Strategic Management Journal. Volume 6, Issue 3 July/September 1985 Pages 273-293.

[11] Bakar, Abdul Rahim Abu; Hashim, Fariza; Ahmad, Hartini; Isa, Filzah Md; Dzakaria, Hisham. International Journal of Marketing Studies1.2 (Nov 2009): 158-164.

[12] Hanif. Rahmat;Arif Masood;Samra Tariq;Dr.Sarvar Azhar. 2012.Strateguc Talent Management as Source of Competitive Advantage "Talent Competitiveness Framework". SSRN

[13] Day, G.S. 1994. The Capabilities of Market driven Organization. Journal of Marketing, Vol.58. p.37-52. Press Cambridge,MA.

[14] Collis, D.J. 1994. "Research note: How valuable are organizational capabilities?'. 1990'2'. Harvard Business Review. July-August. Pp.11828.

[15] Dosi, Giovanni; Richard R. Nelson; dan Sidney G. Winter. 2002. The Nature and Dynamic Oeganizational Capabilities. Oxford University Press. UK. p. 1-10

[16] Lewis, R. E. \& Heckamn, R.J. 2006. Talent Management: A Critical Review. Human Resources Management Review, 16, 139-154.

[17] Stuart-Kotze, Robin, Chris Dunn. 2008. Who Are Your Best People?: How to find, measure and manage your top talent. Financial Times, Prentice Hall; 1 edition (8 April 2010).

[18] Kamil, Bidayatul Akmal Mustafa; Dr. Zabeda Abdul Hamid; Prof. Dr. Junaidah Hashim; Dr. Azura Omar. 2012. A STUDY ON THE IMPLEMENTATION OF TALENT MANAGEMENT PRACTICES AT MALAYSIAN COMPANIES. Asian Journal of Business and Management Sciences. Vo. 1 No. 4 (148-149).

[19] Amstrong, Michael. 2006. A Handbook Human Resources Management Practice. 10th Ed. London and Philadelphia: Kogan Page. 